\title{
Genetic variation and phylogenetic relationships among worldwide collections of the Russian wheat aphid, Diuraphis noxia (Mordvilko), inferred from allozyme and RAPD-PCR markers
}

\author{
G. J. PUTERKA, ${ }^{* 1}$ W. C. BLACK $N_{1}^{2}$ W. M. STEINER ${ }^{3}$ \& R. L. BURTON \\ USDA-ARS, Plant Science Research Laboratory, 1301 N. Western, Stillwater, OK 74075, U.S.A.
}

\begin{abstract}
Genetic analyses were conducted on Diuraphis noxia (Mordvilko) populations collected from wheat, barley and other grasses from various countries throughout the world. These collections had been found to contain clones that differed in virulence from various cultivars, cuticular hydrocarbon profiles and life cycle characters. Discrete genetic markers analysed in this study included allozymes and arbitrary regions of the genome amplified by the polymerase chain reaction (RAPD-PCR). In all, 23 enzymes were evaluated; 17 of these enzymes representing 20 isozyme loci, were judged suitable for allozyme analysis. Polymorphisms were detected at three (15 per cent) loci: $\beta$-esterase $(\beta-E S T)$, phosphoglucose isomerase $(P G I)$, and 6-phosphogluconate dehydrogenase $(6-P G D H)$. The average expected heterozygosity amongst these loci was 4.9 per cent in the worldwide collection. Allozyme variation was absent within most populations, particularly within those countries where the species was recently introduced. Much greater genetic variation was detected when populations were analysed with RAPD-PCR. Populations were analysed with 69 polymorphic bands amplified by seven primers. All populations could be distinguished with this method. Cluster analyses indicated strong similarities between U.S.A. populations and collections from South Africa, Mexico, France and Turkey. The most variation was detected among populations from the Middle East and southern Russia.
\end{abstract}

Keywords: allozymes, aphid, biotypes, Diuraphis noxia, population genetics, RAPD-PCR.

\section{Introduction}

The Russian wheat aphid, Diuraphis noxia (Mordvilko), is an important pest of small grains that is indigenous to cereal-producing regions of the Middle East, Asia Minor and southern Russia, where it has caused significant losses to wheat, Triticum aestivum L., and barley, Hordeum vulgare L., since 1900 (Grossheim, 1914). Recently, accidental introductions have extended the range of $D$. noxia to other cereal-

\footnotetext{
* Correspondence.

1 Present address: USDA-ARS, Appalachian Fruit Research Station, 45 Wiltshire Road, Kearneysville, West Virginia 25430.

${ }^{2}$ Arthropod Borne and Infectious Disease Laboratory, Foothills Campus, Colorado State University, Fort Collins, Colorado 80523.

${ }^{3}$ USDA-ARS, Biological Control of Insect Laboratory, P.O. Box 7629, Columbia, Missouri 65205
}

producing areas of the world. In $1978, D$. noxia appeared in South Africa (Walters et al., 1980) and, in 1980, it was discovered in Mexico (Gilchrist et al., 1984). By 1986, the species had migrated into the southwestern U.S.A., possibly from Mexico and rapidly spread throughout the western wheat-producing areas of the U.S.A. and Canada (Stoetzel, 1987). This aphid has the ability to utilize a large number of grasses (Kindler \& Springer, 1989) other than cereals, increasing the likelihood of establishment in new habitats. Furthermore, both anholocyclic and holocyclic reproduction is known in $D$. noxia populations (Kiriac et al., 1990). Anholocycly, continuous parthenogenetic reproduction by apomictic thelytoky, enables rapid establishment of existing aphid genotypes. Holocycly, parthenogenetic reproduction interrupted by an annual sexual generation in the fall, 
enables populations to overwinter in the egg stage in areas where winters are too harsh to allow host plants or adult aphids to overwinter. Sexual reproduction also produces new genotypes in the spring that may be better adapted to survive in new habitats (Blackman, 1985). Sexual reproduction is a factor in host race or biotype development, a phenomenon that commonly occurs in aphids (Briggs, 1965; Puterka \& Peters, 1989, 1990; Puterka \& Burton, 1991) and which has been documented in D. noxia (Puterka et al., 1992).

Identifying the breeding structure of introduced insect species is necessary to understand and monitor genetic changes that occur as populations adapt to new regions. Furthermore, genetic polymorphisms provide a means of identifying the origin(s) of newly-introduced populations (Powell et al., 1980; Kamhampati et al., 1991). Isozyme electrophoresis has been useful in identifying markers for studies of aphid breeding structure (Tomiuk et al., 1979; Singh \& Cunningham, 1981; Loxdale et al., 1983; Tomiuk \& Wohrmann, 1983; Steiner et al., 1985a). However, polymorphisms are typically detected at a few loci (Wool et al., 1978; Loxdale et al., 1985; Rhomberg et al., 1985; Steiner et al., 1985b) and in several aphid species no variation has been found (May \& Holbrook, 1978; Tomiuk \& Wohrmann, 1980; Loxdale et al., 1983; Beregovoy \& Starks, 1986). Substantially more genetic variation has been detected using mitochondrial DNA/restriction fragment length polymorphisms (mtDNA-RFLPS) (Powers et al., 1989; ) and DNA fingerprinting probes (Carvalho et al., 1991; Shufran et al., 1991). Recently, genetic polymorphisms revealed by RAPD-PCR (Random Amplified Polymorphic DNA amplified by the Polymerase Chain Reaction)(Williams et al., 1990) have been demonstrated in several species of aphids and aphid parasitoids (Black et al., 1992).

No genetic studies have been conducted on $D$. noxia. The recent dispersal of the species throughout the world makes baseline genetic information essential. In this study, we explore the use of allozymes and RAPD-PCR markers to investigate the genetic composition of $D$. noxia populations worldwide. The study was conducted to describe phylogenetic relationships among populations and biotypes of this important pest species.

\section{Materials and methods}

\section{D. noxia collections}

D. noxia collections from wheat, barley or other grasses were obtained from various countries throughout the world with intensive sampling conducted in the U.S.A. (Table 1). Aphids were collected from different colonies in three or more locations in each field and consolidated to achieve a sample of 100 or more aphids per field; one to three fields were sampled for each country or state and kept separate. Aphid collections inside the U.S.A. were placed in petri dishes that contained live plant material and shipped alive.

Collections from outside the U.S.A. were placed in vials, transported on ice to the laboratory, frozen at $-10^{\circ} \mathrm{C}$, and shipped on dry ice to preserve enzyme activity. All samples were placed in liquid nitrogen for long-term storage. Mixed aphid samples from Syria were freeze dried for shipment and were suitable only for RAPD-PCR analysis.

The collections include seven clones found to exhibit biotypic variation on various cereal cultivars (Puterka et al., 1992). We also examined three clones collected in Texas in 1986 that were shown to cause slight differences in damage to susceptible wheat (Bush et al., 1989), 10 clones that were known to differ in life cycle (Kiriac et al., 1990), and a clone collected from Oklahoma in 1988 that was found to differ in its cuticular hydrocarbon profile from other U.S.A. isolates (Bergman et al., 1990).

Aphids were sampled from 24 locations in the U.S.A. Clonal lines were established from 23 of these locations. In 11 locations, more than 100 aphids were collected directly from the field and used to analyse genetic variation within each population. Aphids were cloned by placing an individual aphid on 'TAM W-101' wheat in a growth chamber provided with a temperature of $21^{\circ} \mathrm{C}, 12: 12 \mathrm{~L}: \mathrm{D}$ photophase, and allowing the aphid to reproduce parthenogenetically for 1 month. The 11 uncloned populations were reared for one generation to eliminate parasitoid contamination that could lead to erroneous results.

\section{Enzyme electrophoresis}

Starch gel electrophoresis of enzymes was conducted using the equipment and methods outlined by Steiner \& Joslyn (1979) with a few modifications of gel and electrode buffers and voltage. Only two buffer systems were used to examine all enzymes. In the lithium hydroxide $(\mathrm{LiOH})$ system, the gel and electrode $p \mathrm{Hs}$ were adjusted to 8.5 and 8.4 , respectively. The $\mathrm{LiOH}$ buffer system was adjusted (gel $p \mathrm{H}=8.7$, electrode $p \mathrm{H}=8.5,200 \mathrm{~V}$ for $3.5 \mathrm{~h}$ ) to obtain satisfactory resolution of $\beta$-EST. In addition, the sample was diluted by doubling the amount of grinding solution. Differential staining of $\alpha$ - and $\beta$-esterases was performed using methods described by Singh \& Cunningham (1981). The Tris-citrate buffer system used was CA-8 (Steiner \& Joslyn, 1979) with the gel and electrode $p \mathrm{H}$ changed to 8.5 and 8.0 , respectively. 
Table 1 List of D. noxia collections used in the genetic analyses

\begin{tabular}{|c|c|c|c|}
\hline $\begin{array}{l}\text { Location of } \\
\text { collection }\end{array}$ & $\begin{array}{l}\text { Host } \\
\text { plant }\end{array}$ & $\begin{array}{l}\text { Year } \\
\text { collected }\end{array}$ & $\begin{array}{l}\text { Type of } \\
\text { collection' }^{1}(n)\end{array}$ \\
\hline Imperial County, $\mathrm{CA}^{6}$ & Wheat & 1990 & $\mathrm{C}, \mathrm{P}(3)$ \\
\hline Larimer County, $\mathrm{CO}^{6}$ & Wheat & 1989 & $\mathrm{C}$ \\
\hline Latah County, Idaho ${ }^{6}$ & Wheat & 1989 & $\mathrm{C}$ \\
\hline Ellis County, $\mathrm{KS}^{6}$ & Wheat & 1989 & $\mathrm{C}$ \\
\hline Wheatland County, $\mathbf{M T}^{6}$ & Wheat & 1989 & $\mathrm{C}, \mathrm{P}(3)$ \\
\hline Wheatland County, MT & Wheat & 1990 & $\mathrm{C}$ \\
\hline Scottsbluff County, NB ${ }^{6}$ & Wheat & 1989 & $\mathrm{C}, \mathbf{P}(2)$ \\
\hline Cheyenne County, NB & Wheat & 1989 & $C, P(1)$ \\
\hline Torrence County, NM ${ }^{6}$ & Wheat & 1989 & $\mathrm{C}, \mathrm{P}(1)$ \\
\hline Torrence County, NM & Oat & 1989 & $\mathrm{C}$ \\
\hline Churchill County, NV & Wheat & 1990 & $\mathrm{C}, \mathrm{P}(2)$ \\
\hline Churchill County, NV & Barley & 1990 & $P(1)$ \\
\hline Jackson County, $\mathrm{OK}^{2}$ & Wheat & 1988 & $\mathrm{C}$ \\
\hline Umatilla County, $\mathrm{OR}^{6}$ & Wheat & 1989 & $\mathrm{C}, \mathrm{P}(2)$ \\
\hline Umatilla County, OR & Wheatgrass & 1989 & $\mathrm{C}, \mathrm{P}(1)$ \\
\hline Bailey County, TX & Wheat & 1986 & $\mathrm{C}$ \\
\hline Potter County, TX & Wheat & 1989 & $\mathrm{C}$ \\
\hline Lubbock County, $\mathrm{TX}^{3,4}$ & Wheat & 1989 & $\mathrm{C}, \mathrm{P}$ \\
\hline Knox County, TX $^{5}$ & Wheat & 1986 & $\mathrm{C}$ \\
\hline Scurry County, $\mathrm{TX}^{5}$ & Wheat & 1986 & $\mathrm{C}$ \\
\hline Tom Green County, $\mathrm{TX}^{5}$ & Wheat & 1986 & $\mathrm{C}$ \\
\hline Laramie County, WY & Wheatgrass & 1989 & $\mathrm{C}$ \\
\hline Laramie County, WY & Wheat & 1989 & $\mathrm{C}, \mathrm{P}(1)$ \\
\hline Fremont County, WY & Barley & 1989 & $\mathrm{C}$ \\
\hline Alberta, Canada ${ }^{6}$ & Wheat & 1989 & $P(2)$ \\
\hline Seranon, France ${ }^{4-6}$ & Wheat & 1989 & $\mathrm{C}$ \\
\hline Antibes, France ${ }^{4-6}$ & Wheat & 1989 & $\mathrm{C}, \mathrm{P}(1)$ \\
\hline Disi, Jordan ${ }^{4-6}$ & Wheat & 1989 & $\mathrm{C}$ \\
\hline Iachmen, Kirghiz ${ }^{4-6}$ & Wheat & 1989 & $\mathrm{C}$ \\
\hline Mexico City, Mexico ${ }^{6}$ & Wheat & 1990 & $\mathrm{C}$ \\
\hline Komrat, Moldavia ${ }^{4-6}$ & Barley & 1989 & $\mathrm{C}$ \\
\hline Bethlehem, South Africa $^{6}$ & Wheat & 1990 & $\mathrm{P}(3)$ \\
\hline Aleppo, Syria ${ }^{4-6}$ & Wheat & 1989 & $\mathrm{C}, \mathrm{P}(3)$ \\
\hline Beyparazi, Turkey ${ }^{4-6}$ & Wheat & 1989 & $\mathrm{C}$ \\
\hline Crimean Peninsula, Ukraine ${ }^{4}$ & Wheat & 1989 & $P(1)$ \\
\hline Kerson, Ukraine ${ }^{4}$ & Wheat & 1989 & $P(1)$ \\
\hline
\end{tabular}

${ }^{1} \mathrm{C}=$ clone; $\mathrm{P}=$ population, separate collections of $\geq 100$ individuals collected from one to three different fields $(n)$.

${ }^{2}$ Clone found to differ in cuticular hydrocarbon profile from other $D$. noxia from the U.S.A. (Bergman et al., 1990).

${ }^{3}$ Collections determined to exhibit biotypic variation (Puterka et al., 1992).

${ }^{4}$ Collections found to differ in life cycle (Kiriac et al., 1990)

${ }^{5}$ Clones differing slightly in virulence (Bush et al., 1989).

${ }^{6}$ Mixed population analysed with RAPD-PCR.

Aphid homogenates were prepared by placing one large aphid (two smaller aphids from clones) into the well of a standard 64-well flat bottom microtiter plate positioned on an ice pack, adding $15 \mu \mathrm{l}$ of grinding solution made of 10 per cent sucrose and 0.01 per cent Triton X-100 in distilled water (Black \& Krafsur,
1985), and grinding the aphid by hand with a $6 \mathrm{~mm}$ glass rod. Samples prepared with and without Triton $\mathrm{X}-100$ revealed that the detergent significantly enhanced enzyme activity. The aphid homogenates were absorbed into $4 \mathrm{~mm} \times 5 \mathrm{~mm}$ squares of Whatman number 2 filter paper and loaded into the slot of an 
11.5 per cent starch gel that was $19 \mathrm{~cm}$ wide $\times 11 \mathrm{~cm}$ long $\times 6 \mathrm{~mm}$ thick. The last lane of the gel was loaded with a tracking dye $(0.5$ per cent bromophenol blue, 30 per cent sucrose in distilled water). Up to 30 aphid samples, plus two tracking dye lanes, could be loaded in one gel. The gel was chilled by a tray of ice placed on top during the run. Electrophoresis was performed at a constant $120 \mathrm{~V}$ for $4 \mathrm{~h}$ or until the tracking dye migrated $9 \mathrm{~cm}$ from the origin. Afterwards, the paper squares were removed and the gel was sectioned horizontally into four or five, $1 \mathrm{~mm}$ thick slices. This allowed four to five different enzymes to be evaluated from a single aphid.

The 23 enzyme systems were tested to identify those that yielded good resolution and activity. Four to six replications (individual gels) for each of the 23 enzymes were performed on the clones to test for polymorphisms within clones. A total of 28 individuals were surveyed per enzyme locus in uncloned field populations represented by a single collection, whereas 20 individuals were surveyed per collection in populations represented by one to three field collections.

For each enzyme stain, the activity and numbers of presumptive loci and alleles were scored. Band mobility was scored as a proportion of the mobility of the most common band. The percentage of loci found to be polymorphic and the average expected heterozygosity were calculated within the entire worldwide aphid collection. Phylogenetic analysis was conducted on aphid populations using Nei's unbiased genetic distances (Nei, 1978) among populations and a dendrogram was constructed using the UPGMA algorithm in BIOSYS-1 (Swofford \& Selander, 1981).

\section{RAPD-PCR analysis}

The DNA isolation procedures, PCR buffers, protocols and products are described in Black et al. (1992). A total of 14 primers were initially screened in populations from Jordan, France, Syria and California (U.S.A.) to identify primers that consistently revealed well amplified, polymorphic bands. The BAM and ECO primers described in Black et al. (1992) were used in addition to primers $\mathrm{C} 01$ through $\mathrm{C} 12$ from Operon Technologies Inc. (Table 2). Only 18 of the populations listed in Table 1 were analysed. In uncloned samples from Jordan, France (two locations), Syria, California, Canada and South Africa, we analysed 10 individuals with the BAM primer to estimate variation within populations.

Each band in an aphid was scored as 1, if present, or 0 , if absent. The fraction of bands matching in two aphids $(M)$ was calculated using the formula:

\section{$M=N_{\mathrm{AB}} / N_{\mathrm{T}}$}

where $N_{\mathrm{AB}}$ is the total number of matches (i.e. both bands absent or both bands present) in individuals $A$ and $B$ and $N_{\mathrm{T}}$ is the total number of fragments scored. $A$ value of 1 for both measures indicated that two individuals had identical patterns; a value of 0 indicated that two individuals had completely different patterns.

Cluster analyses were performed using an unweighted pair-group method algorithm (UPGMA) on the values of $1-M$. Dendrographs were plotted using the within-group and between-group values calculated using modifications of the FORTRAN

Table 2 RAPD-PCR markers analysed in 18 worldwide collections of $D$. noxia

\begin{tabular}{|c|c|c|c|}
\hline Primer name Sequence & $\begin{array}{l}\text { Number of } \\
\text { polymorphic bands }\end{array}$ & $\begin{array}{l}\text { Well-amplified } \\
\text { polymorphic bands }\end{array}$ & $\begin{array}{l}\text { Faint } \\
\text { polymorphic bands }\end{array}$ \\
\hline BAM $\quad 5^{\prime}$ ATGGATCCGC-3' & 15 & 15 & 0 \\
\hline ECO $\quad 5^{\prime}$-ATGAATTCGC- $3^{\prime}$ & 3 & 3 & 0 \\
\hline CO1 $\quad 5^{\prime}$-TTCGAGCCAG- $3^{\prime}$ & 11 & 0 & 11 \\
\hline $\mathrm{CO} 255^{\prime}$-GTGAGGCGTC- $3^{\prime}$ & 0 & 0 & 0 \\
\hline CO3 5'-GGGGGTCTTT-3' & 0 (no products) & 0 & 0 \\
\hline CO4 5 '-CCGCATCTAC-3' & 10 & 1 & 9 \\
\hline CO5 $\quad 5^{\prime}$-GATGACCGCC- $3^{\prime}$ & 0 & 0 & 0 \\
\hline CO6 5'-GAACGGACTC-3' & 10 & 1 & 9 \\
\hline CO7 5'-GTCCCGACGA-3' & 6 & 2 & 4 \\
\hline CO8 $\quad 5^{\prime}$-TGGACCGGTG-3' & 0 & 0 & 0 \\
\hline CO9 5'-CTCACCGTCC-3' & 0 & 0 & 0 \\
\hline C10 5'-TGTCTGGGTG-3' & 0 & 0 & 0 \\
\hline C11 5'-AAAGCTGCGG-3' & 14 & 6 & 8 \\
\hline C12 $5^{\prime}$-TGTCATCCCC- $3^{\prime}$ & 0 & 0 & 0 \\
\hline Total & 69 & 28 & 41 \\
\hline
\end{tabular}


program of McCammon \& Wenninger (1970). Our modification of this program for RAPD-PCR markers is called 'RAPDPLOT' (Kambhampati et al., 1992) and is available from WCB.

\section{Results}

\section{Enzyme electrophoresis}

Active and well resolved bands were produced in 17 of the 23 enzyme stains tested. These stains, the 20 presumptive loci they reveal, the numbers of presumptive alleles per locus, the buffer systems used, and the different aphid genotypes are listed in Table 3. The numbers of loci encoding each enzyme are consistent with those reported in other aphids (Steiner, 1988), with the exception of leucine aminopeptidase (LAP). The LAP enzyme in aphids commonly has two loci represented by two to four bands, but we detected a single $L A P$ locus in $D$. noxia. Strong differential activity was observed when staining for $\alpha$ - and $\beta$ esterases (EST). The $\alpha$-EST was represented by three widely spaced monomorphic bands while $\beta$-EST bands did not leave the origin using the standard CA- 8 buffer system. The $\alpha$-EST bands migrated off the gel long before the $\beta$-EST bands began to migrate when using the modified CA-8 buffer system. Analysis of $\alpha$-EST was abandoned so $\beta$-EST could be evaluated. Enzymes that had too low or no activity were fumarase (FUM), hydroxybutyrate dehydrogenase (HBDH), triose phosphate isomerase (TPI), superoxide dismutase (SOD), acid phosphatase $(\mathrm{ACPH})$ and peptidase (PEP).

Of the 20 loci examined, three (15 per cent) were found to be polymorphic: $\beta$-EST, phosphoglucose isomerase (PGI), and 6-phosphogluconate dehydrogenase (6-PGDH) (Table 3, Fig. 1). Polymorphic esterase loci have been reported in other aphids (Beranek, 1974; Wool et al., 1978; Simon et al., 1982). Variation in the PGI enzyme has been reported among populations of Rhopalosiphum maidis (Fitch) (Steiner et al., 1985b) and a polymorphic 6-PGDH locus was discovered among biotypes of Schizaphis graminum (Rondani) (Abid et al., 1989). The average expected heterozygosity was 4.9 per cent in the 31 world populations examined.

Table 3 The 17 enzymes consisting of 20 presumptive enzyme loci used to evaluate genetic variation in $D$. noxia

\begin{tabular}{|c|c|c|c|}
\hline Enzyme & Buffer system & Number of bands & Genotypes \\
\hline Alcohol dehydrogenase (ADH) & $\mathrm{LiOH}$ & 1 & $100 / 100$ \\
\hline Aldehyde oxidase (ALDOX) & $\mathrm{LiOH}$ & 1 & $100 / 100$ \\
\hline Adenylate kinase-1 (ADK-1) & CA-8 & 2 & $77 / 100$ \\
\hline Adenylate kinase-2 (ADK-2) & CA-8 & 2 & $57 / 100$ \\
\hline$\beta$-Esterase $(\beta$-EST $)$ & CA-8 & $1-3$ & $70 / 100,29 / 29,29 / 70 / 100$ \\
\hline $\begin{array}{l}\text { Glucose-6-phosphate } \\
\text { dehydrogenase (G-6-PDH) }\end{array}$ & CA-8 & 1 & $100 / 100$ \\
\hline $\begin{array}{l}\text { Glutamate oxaloacetate } \\
\text { transaminase-1 (GOT-1) }\end{array}$ & $\mathrm{LiOH}$ & 1 & $100 / 100$ \\
\hline $\begin{array}{l}\text { Glutamate oxaloacetate } \\
\text { transaminase-2 (GOT-2) }\end{array}$ & $\mathrm{LiOH}$ & 1 & $100 / 100$ \\
\hline $\begin{array}{l}\alpha \text {-Glycerophosphate } \\
\text { dehydrogenase }(\alpha \text {-GPDH })\end{array}$ & CA-8 & 1 & $100 / 100$ \\
\hline $\begin{array}{l}\text { Glyceraldehyde-3-phosphate } \\
\text { dehydrogenase (G-3-PDH) }\end{array}$ & CA-8 & 1 & $100 / 100$ \\
\hline Hexokinase-1 (HK-1) & CA-8 & 2 & $100 / 130$ \\
\hline Hexokinase-2 (HK-2) & CA-8 & 1 & $100 / 100$ \\
\hline Leucine aminopepetidase (LAP) & $\mathrm{LiOH}$ & 1 & $100 / 100$ \\
\hline Malic dehydrogenase (MDH) & CA- 8 & 2 & $100 / 130$ \\
\hline Malic enzyme (ME) & $\mathrm{LiOH}$ & 2 & $100 / 113$ \\
\hline Phosphoglucose isomerase (PGI) & $\mathrm{LiOH}$ & 1 or 2 & $100 / 100,100 / 119$ \\
\hline Phosphoglucomutase (PGM) & $\mathrm{LiOH}$ & 1 or 2 & $100 / 118$ \\
\hline $\begin{array}{l}\text { 6-Phosphogluconate } \\
\text { dehydrogenase }(6-\mathrm{PGDH})\end{array}$ & CA- 8 & 3 & $100 / 100,100 / 115 / 130$ \\
\hline Octanol dehydrogenase $(\mathrm{ODH})$ & $\mathrm{LiOH}$ & 1 & $100 / 100$ \\
\hline Xanthine dehydrogenase $(\mathrm{XDH})$ & $\mathrm{LiOH}$ & 1 & $100 / 100$ \\
\hline
\end{tabular}




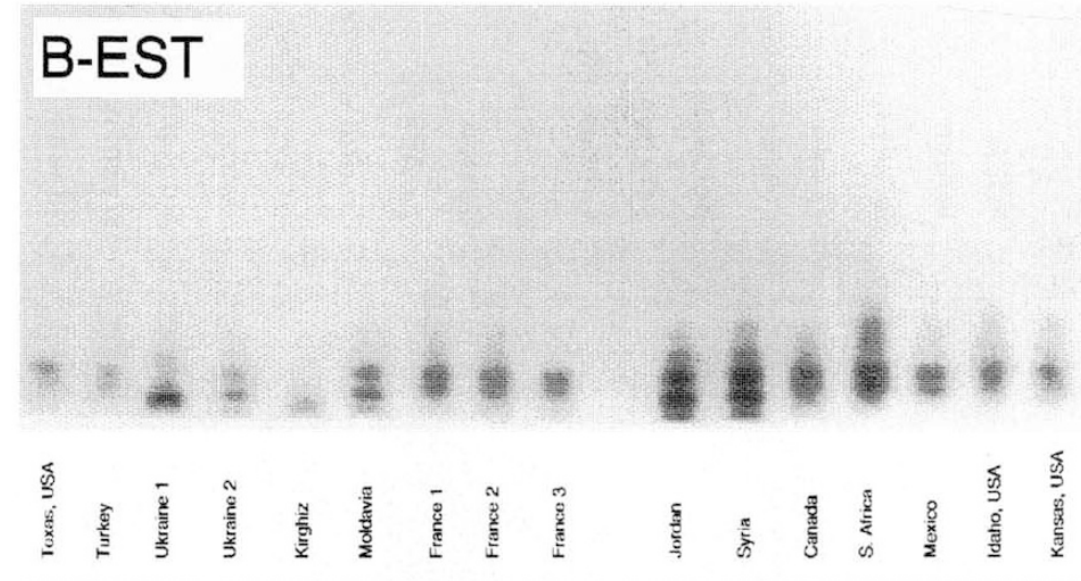

\section{6-PGDH}

Fig. 1 Allozyme patterns for the three polymorphic enzyme loci among a worldwide collection of $D$. noxia using starch gel (12 per cent) electrophoresis. Ukraine $1=$ Crimean, Ukraine; Ukraine $2=$ Kerson, Ukraine; France $1=$ Antibes, France; France $2=$ Seranon, France; France $3=$ Behoust, France.

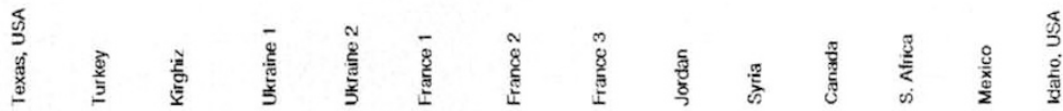

\section{PGI}

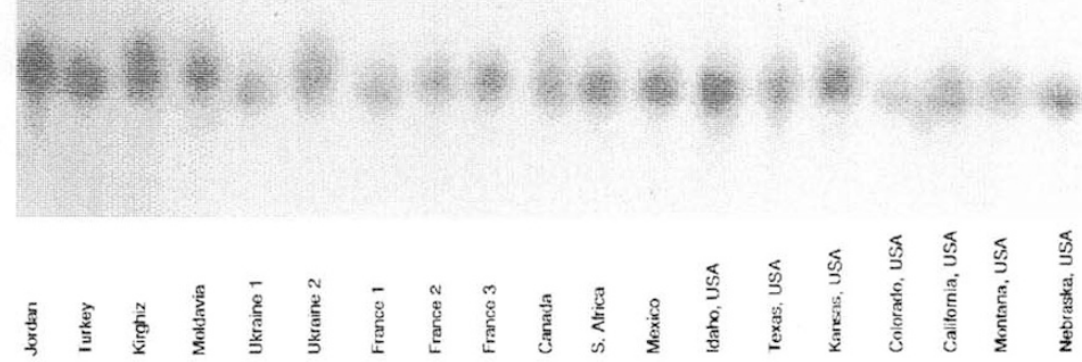

\section{RAPD-PCR analysis}

Primer sequences and the number of bands scored are listed in Table 2. Bands revealed by RAPD-PCR using the BAM primer and the $\mathrm{C} 04$ primer among several world populations are displayed in Fig. 2A and B. For comparison of all world populations, 69 bands amplified by seven primers (ECO, BAM, CO1, C04, C06, $\mathrm{C} 07$ and $\mathrm{C} 11$ ) were used. The sizes of bands amplified by each primer are listed in Table 4 . The occurrences of these 69 bands in the 18 populations are listed in
Table 5. A second analysis was completed using only well amplified polymorphic bands. There were 28 of these distributed among all seven primers except $\mathrm{C} 01$ (Table 4).

\section{Genetic variation within aphid populations}

Genotypes revealed using either allozyme (Table 6) or RAPD-PCR markers (Table 7) were consistent within aphid clones supporting the observation that parthenogenesis in $D$. noxia produces offspring that do not 


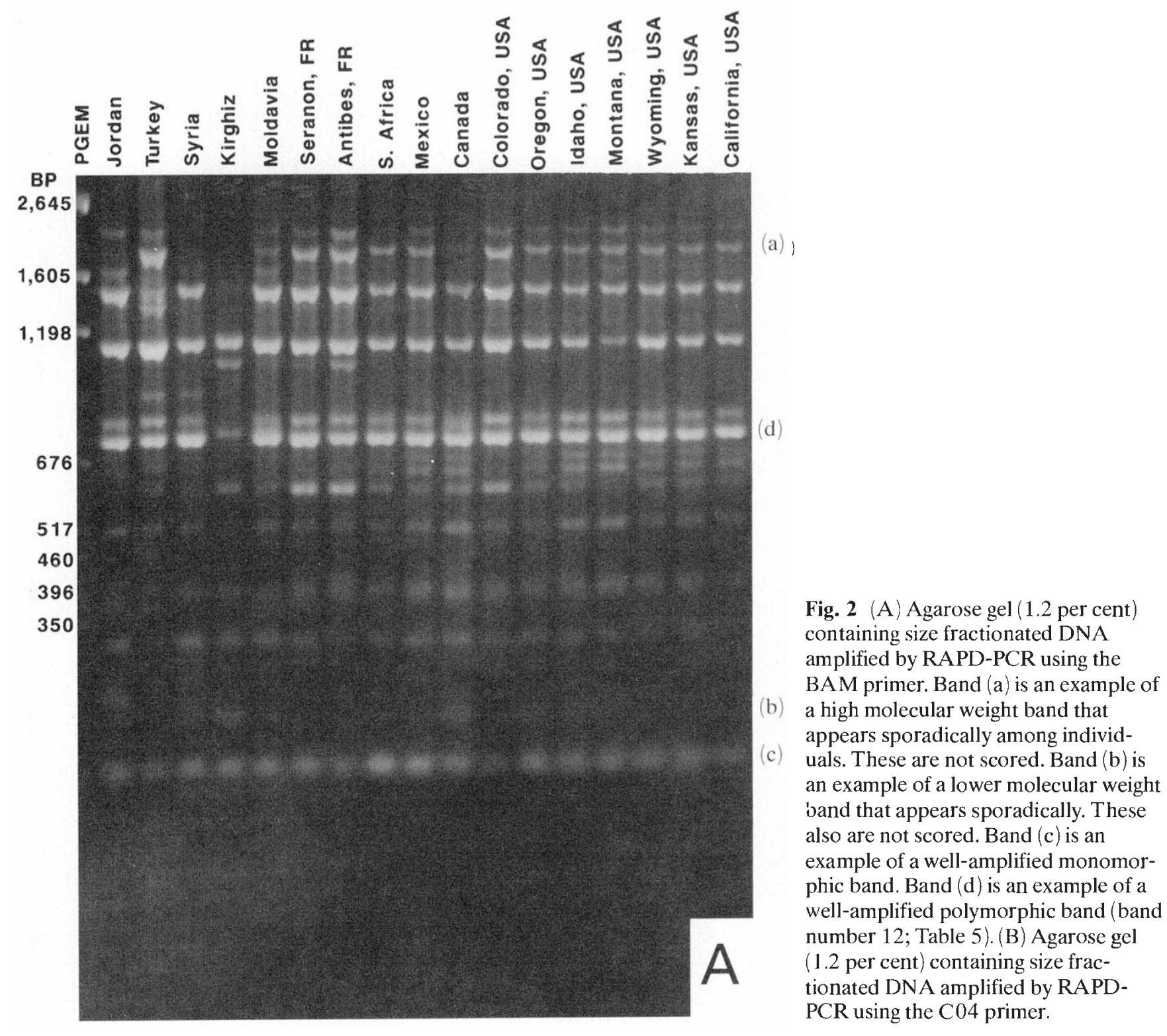

differ genetically from their stem-mother as in other aphid species (Suomalainen et al., 1980). In all populations examined with enzyme markers, virtually no genetic variation was observed, particularly in populations collected in those countries where $D$. noxia was recently introduced. The single exception was the Ukrainian population in which two distinct genotypes were found, yet even here there was a lack of allozyme variation within individual collections. Similarly, with the exception of two genotypes in South Africa, very little intrapopulational variation was observed in RAPD-PCR markers in uncloned samples from by which we analysed 10 individuals per population (Table 7).

\section{Genetic variation among aphid populations}

Five distinct aphid genotypes were detected based on the three polymorphic allozyme loci. Clones from the Crimean Peninsula, Ukraine (Ukraine 1); Jordan; and Syria were of the same genotype. The Kerson, Ukrainian (Ukraine 2); Kirghizian; and Moldavian $D$. noxia were each a unique genotype, while populations in the remainder of the countries were all a single distinct genotype. The allelomorph occurring in Turkey was especially noteworthy in that it differed from all other clones in the Mediterranean region, but was identical to other $D$. noxia populations recently established in distant geographical areas throughout 


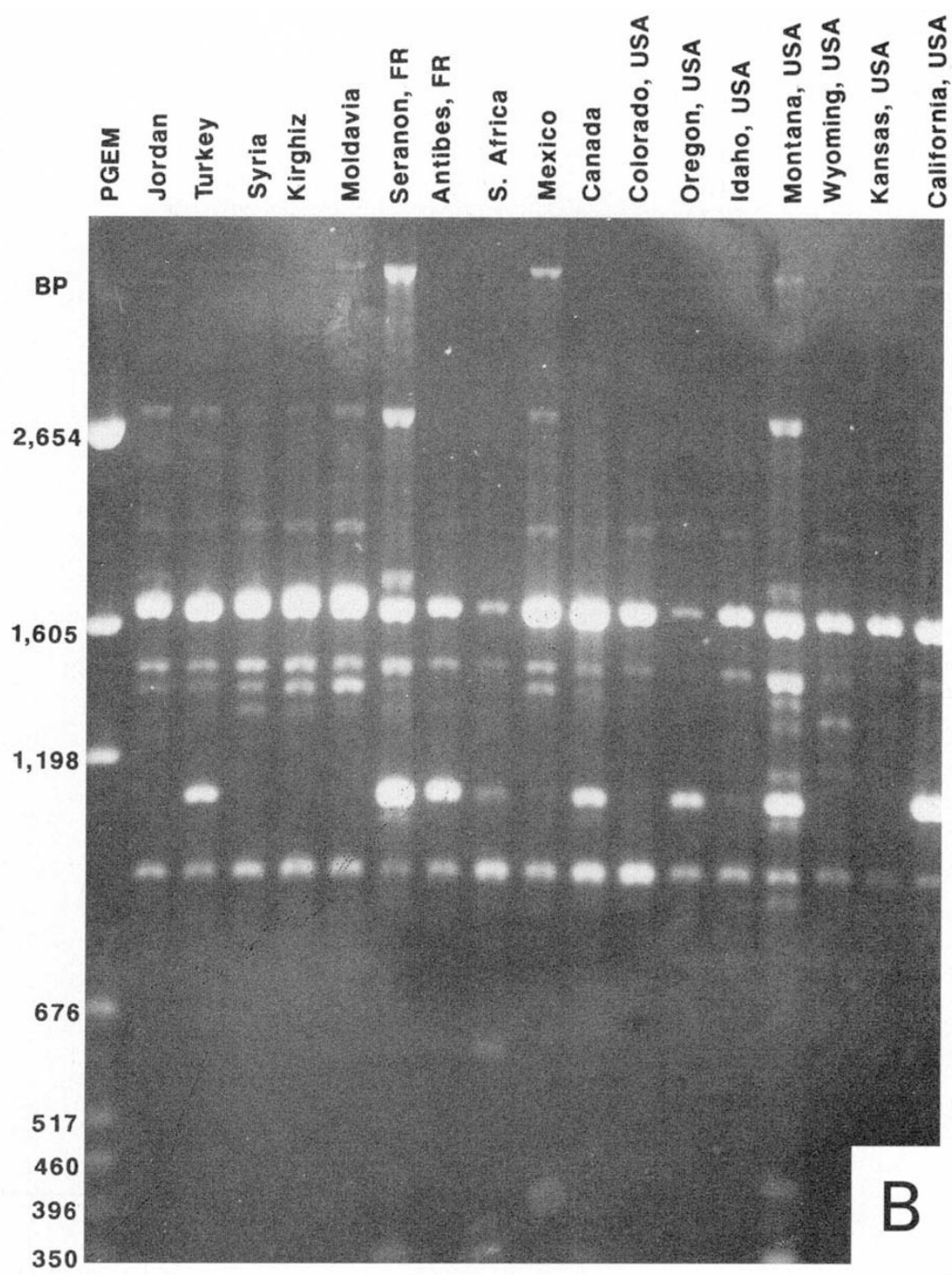

the world. Genetic relationships among $D$. noxia populations based on allozyme data are depicted in a dendrogram (Fig. 3). This analysis grouped the populations into five distinct clusters. These clusters correspond with geographic regions to some degree (i.e. Jordan, Syria, Ukraine 1 and Canada, Mexico, U.S.A.). However, a large genetic distance did exist between the Ukraine populations.

We had originally intended to perform analyses of band frequencies in all populations but so little variation in RAPD-PCR profiles was detected within the six uncloned field collections that bands common to all members of a population were grouped into a single profile. The UPGMA dendrogram based on $1-M$ using all 69 polymorphic markers or 28 well-amplified markers (Table $4 \mathrm{~g}$ ) are displayed in Fig. 4A\&B. In contrast to the alloyzme dendrogram, all populations could be differentiated using RAPD-PCR markers.

In both RAPD-PCR dendrograms, all of the populations that clustered as a single allozyme genotype also clustered on a single branch. The U.S.A. populations also clustered with Mexico, South Africa, France and Turkey. There was no correspondence between geographical distance and $1-M$ in U.S.A. populations with either dendrograms. Populations from adjacent states did not cluster. Furthermore, the two populations from southern France did not cluster, and Syria clustered with Moldavia rather than Jordan when using 
Table 4 Sizes (base pairs) of bands amplified by RAPDPCR in D. noxia populations. Well amplified polymorphic bands are indicated by an *

\begin{tabular}{|c|c|c|c|c|c|}
\hline \multirow{2}{*}{\multicolumn{3}{|c|}{$\begin{array}{l}\text { PCR in D. noxia populations. Well amplified polymorphic } \\
\text { bands are indicated by an * }\end{array}$}} & \multirow{3}{*}{$\begin{array}{l}\text { Band } \\
\text { number }\end{array}$} & \multirow{2}{*}{ Primer } & \multirow{3}{*}{$\begin{array}{l}\text { All polymorphic } \\
\text { bands }\end{array}$} \\
\hline & & & & & \\
\hline \multirow{2}{*}{$\begin{array}{l}\text { Band } \\
\text { number }\end{array}$} & \multirow[b]{2}{*}{ Primer } & \multirow{2}{*}{$\begin{array}{l}\text { All polymorphic } \\
\text { bands }\end{array}$} & & & \\
\hline & & & $\begin{array}{l}35 \\
36\end{array}$ & $\begin{array}{l}\mathrm{CO} 4 \\
\mathrm{CO} 4\end{array}$ & $\begin{array}{c}1090^{*} \\
870\end{array}$ \\
\hline 1 & $\mathrm{ECO}$ & $1620^{*}$ & 37 & $\mathrm{CO} 4$ & 610 \\
\hline 2 & $\mathrm{ECO}$ & $1150^{*}$ & 38 & $\mathrm{CO} 4$ & 410 \\
\hline 3 & ECO & $990^{*}$ & 39 & $\mathrm{CO} 4$ & 340 \\
\hline 4 & BAM & $2140^{*}$ & 40 & CO6 & 2650 \\
\hline 5 & BAM & $1900^{*}$ & 41 & CO6 & 1980 \\
\hline 6 & BAM & $1650^{*}$ & 42 & $\mathrm{CO} 6$ & 1890 \\
\hline 7 & BAM & $1450^{*}$ & 43 & CO6 & 1780 \\
\hline 8 & BAM & $1320^{*}$ & 44 & CO6 & 1370 \\
\hline 9 & BAM & $1020^{*}$ & 45 & CO6 & 1140 \\
\hline 10 & BAM & $900^{*}$ & 46 & CO6 & 940 \\
\hline 11 & BAM & $790^{*}$ & 47 & $\mathrm{CO} 6$ & $760^{*}$ \\
\hline 12 & BAM & $740^{*}$ & 48 & $\mathrm{CO} 6$ & 630 \\
\hline 13 & BAM & $590^{*}$ & 49 & $\mathrm{CO} 6$ & 450 \\
\hline 14 & BAM & $520^{*}$ & 50 & $\mathrm{CO} 7$ & 1540 \\
\hline 15 & BAM & $440^{*}$ & 51 & $\mathrm{CO} 7$ & $1370^{*}$ \\
\hline 16 & BAM & $280^{*}$ & 52 & $\mathrm{CO} 7$ & 900 \\
\hline 17 & BAM & $260^{*}$ & 53 & $\mathrm{CO} 7$ & $850^{*}$ \\
\hline 18 & BAM & $230^{*}$ & 54 & $\mathrm{CO} 7$ & 780 \\
\hline 19 & $\mathrm{CO} 1$ & 1630 & 55 & $\mathrm{CO} 7$ & 450 \\
\hline 20 & $\mathrm{CO} 1$ & 1490 & 56 & $\mathrm{C} 11$ & $1750^{*}$ \\
\hline 21 & $\mathrm{CO} 1$ & 1110 & 57 & $\mathrm{C} 11$ & 1730 \\
\hline 22 & $\mathrm{CO} 1$ & 980 & 58 & C11 & 1740 \\
\hline 23 & $\mathrm{CO} 1$ & 890 & 59 & $\mathrm{C} 11$ & 1600 \\
\hline 24 & $\mathrm{CO} 1$ & 560 & 60 & $\mathrm{C} 11$ & 1500 \\
\hline 25 & $\mathrm{CO} 1$ & 470 & 61 & C11 & $1430^{*}$ \\
\hline 26 & $\mathrm{CO} 1$ & 340 & 62 & C11 & 1370 \\
\hline 27 & $\mathrm{CO} 1$ & 310 & 63 & $\mathrm{C} 11$ & 1220 \\
\hline 28 & $\mathrm{CO} 1$ & 200 & 64 & $\mathrm{C} 11$ & $1010^{*}$ \\
\hline 29 & $\mathrm{CO} 1$ & 170 & 65 & C11 & $810^{*}$ \\
\hline 30 & $\mathrm{CO} 4$ & 1770 & 66 & C11 & 780 \\
\hline 31 & $\mathrm{CO} 4$ & 1450 & 67 & $\mathrm{C} 11$ & $740^{*}$ \\
\hline 32 & $\mathrm{CO} 4$ & 1380 & 68 & $\mathrm{C} 11$ & 500 \\
\hline 33 & $\mathrm{CO} 4$ & 1300 & 69 & C11 & $430^{*}$ \\
\hline 34 & $\mathrm{CO} 4$ & 1160 & & & \\
\hline
\end{tabular}

Table 4 Continued

Table 5 RAPD-PCR bands common to all individuals samples in 18 populations of $D$. noxia. The presence of a band is denoted with a 1 , while its absence is denoted with a 0 . The identity of bands by primer and size appears in Table 4

\begin{tabular}{|c|c|}
\hline & Band number \\
\hline$\frac{\text { D. noxia }}{\text { population }}$ & $\begin{aligned} 1111111111122222222223333333333444444444455555555556666666666 \\
123456789012345678901234567890123456789012345678901234567890123456789\end{aligned}$ \\
\hline Idaho, USA & 011110100011110101000010010000100000000100000100001011100001000100001 \\
\hline Colorado, USA & 1011101000111101000000100000001000000000000000100010010000001100100101 \\
\hline California, USA & 011110100011110100000000001110000000000000000010011010001001001110101 \\
\hline Oregon, USA & 011110100011110101000010001110000010000110000010001010000001100100101 \\
\hline Montana, USA & 011110100011010101000010001111111111011000000010010010000001000110101 \\
\hline Kansas, USA & 011110100011110101000000001110101100000000000000010010000001000110101 \\
\hline Nebraska, USA & 011110100111110000101110001010100010000110001010011010001001001101101 \\
\hline New Mexico, USA & 011110100011110000000010001110100010000110001010011010001001001101101 \\
\hline Canada & 011110100011111101000010001110111010001010001110011010000101001100101 \\
\hline Mexico & 011110100011110101100010100000110000000011101110111010000101101100001 \\
\hline South Africa & 011110100011110101001010001010100010101000011100011010000000000100011 \\
\hline Seranon, FR & 101110101011110100100010001001111010001010001110010010000101001100101 \\
\hline Antibes, FR & 101110101011110100010101010000100010000010001110011010000001001100001 \\
\hline Jordan & 101101100011010110100010101000110000000010011110001000010001010000000 \\
\hline Turkey & 100110110111010100100010101000110010000010001110010010000001001100100 \\
\hline Syria & 101101100111010101001010001010111000000010001110011000011001000000000 \\
\hline Kirghiz, USR & 100000001000101101000101100000111000000010001111010110000001000000000 \\
\hline Moldavia, USR & 101111101011110101100010001000111000000010001110011000011011000000000 \\
\hline
\end{tabular}


Table 6 Genetic variation in a worldwide collection of $D$. noxia based on three polymorphic enzyme loci ${ }^{1}$

\begin{tabular}{|c|c|c|c|c|c|}
\hline \multirow[b]{2}{*}{ Location } & \multirow[b]{2}{*}{$n^{2}$} & \multirow{2}{*}{$\begin{array}{l}\text { Life } \\
\text { cycle }^{3}\end{array}$} & \multicolumn{3}{|l|}{ Genotypes } \\
\hline & & & $\beta$-EST & PGI & 6-PGDH \\
\hline \multicolumn{6}{|l|}{ U.S.A. } \\
\hline Imperial County, CA & 60 & A & $70 / 100$ & $100 / 100$ & $100 / 100$ \\
\hline Wheatland County, MT & 60 & A & $70 / 100$ & $100 / 100$ & $100 / 100$ \\
\hline Scottsbluff County, NB & 40 & A & $70 / 100$ & $100 / 100$ & $100 / 100$ \\
\hline Cheyenne County, NB & 28 & A & $70 / 100$ & $100 / 100$ & $100 / 100$ \\
\hline Torrence County, NM & 28 & A & $70 / 100$ & $100 / 100$ & $100 / 100$ \\
\hline Churchill County, NV & 60 & A & $70 / 100$ & $100 / 100$ & $100 / 100$ \\
\hline Umatilla County, OR & 60 & A & $70 / 100$ & $100 / 100$ & $100 / 100$ \\
\hline Lubbock County, TX & 28 & A & $70 / 100$ & $100 / 100$ & $100 / 100$ \\
\hline Laramie County, WY & 28 & A & $70 / 100$ & $100 / 100$ & $100 / 100$ \\
\hline 23 U.S. cloned colonies & $4-6$ & A & $70 / 100$ & $100 / 100$ & $100 / 100$ \\
\hline Alberta, Canada & 40 & A & $70 / 100$ & $100 / 100$ & $100 / 100$ \\
\hline Antibes, France & 6 & A & $70 / 100$ & $100 / 100$ & $100 / 100$ \\
\hline Seranon, France & 6 & A & $70 / 100$ & $100 / 100$ & $100 / 100$ \\
\hline Behoust, France & 28 & A & $70 / 100$ & $100 / 100$ & $100 / 100$ \\
\hline Disi, Jordan & 6 & A & $29 / 70 / 100$ & $100 / 100$ & $100 / 100$ \\
\hline Iachmen, Kirghiz & 6 & A & $29 / 29$ & $100 / 119$ & $100 / 115 / 130$ \\
\hline Mexico City, Mexico & 6 & A & $70 / 100$ & $100 / 100$ & $100 / 100$ \\
\hline Komrat, Moldavia & 6 & $\mathrm{~A} / \mathrm{H}$ & $29 / 70 / 100$ & $100 / 119$ & $100 / 100$ \\
\hline Bethlehem, South Africa & 40 & A & $70 / 100$ & $100 / 100$ & $100 / 100$ \\
\hline Aleppo, Syria & 6 & A & $29 / 70 / 100$ & $100 / 100$ & $100 / 100$ \\
\hline Beyparazi, Turkey & 6 & A & $70 / 100$ & $100 / 100$ & $100 / 100$ \\
\hline Crimean Peninsula, Ukraine & 28 & $\mathrm{~A} / \mathrm{H}$ & $29 / 70 / 100$ & $100 / 100$ & $100 / 100$ \\
\hline Kerson, Ukraine & 28 & $\mathrm{~A} / \mathrm{H}$ & $29 / 29$ & $100 / 119$ & $100 / 100$ \\
\hline
\end{tabular}

${ }^{1}$ Three polymorphic enzymes were found out of the 17 enzymes ( 20 loci) that were investigated. All seventeen enzymes were investigated in the clone colonies. Three polymorphic enzyme loci plus hexokinase, malate dehydrogenase, malic enzyme, phosphoglucomutase, alcohol dehydrogenase, glucose-6-phosphate dehydrogenase were evaluated for the mixed samples of $D$. noxia.

${ }^{2}$ Number of individuals examined per enzyme locus. Sample locations represented by a clone colony had three gels (replications) per enzyme locus. Mixed samples from locations represented by one field had 28 individuals evaluated per enzyme locus while locations with 2 to 3 fields sampled had 20 individuals per field evaluated making a total of 40-60 individuals evaluated per enzyme locus.

${ }^{3} \mathrm{~A}=$ anholocyclic; $\mathrm{H}=$ holocyclic life cycle; based on Kiriac et al. $(1990)$ and what is generally known about their biology in these countries.

all 69 fragments (Fig. 4A). We interpret this result to indicate that faint bands may not amplify consistently. Therefore, polymorphisms in the occurrence of these bands may reflect vagaries of DNA preparation and amplification rather than actual genetic differences.

\section{Discussion}

The average expected heterozygosity estimated in eight other aphid species ranged from 0 to 4.4 per cent for populations within a country (Rhomberg et al., 1985). The 4.9 per cent estimated in $D$. noxia is among the highest reported for any aphid. However, no heterozygosity was detected in five of the six countries we investigated. Allozyme variation was not detected between the U.S.A. clone that differed in cuticular hydrocarbon profile and the 22 other clones from that country. Furthermore, no allozyme differences were found between the aphid clones collected in Texas in 1986 by Bush et al. (1989) and the D. noxia we collected throughout the western U.S.A. in 1989-90.

A greater number of genetic polymorphisms was detected using RAPD-PCR and, consequently, the technique was better able to discriminate among 
Table 7 RAPD-PCR bands common to 10 individuals sampled in seven populations of $D$. noxia. These represent bands amplified with the BAM primer. The presence of a band is denoted with a 1 , while the absence is denoted with a 0 . The identity of bands by primer and size appears in Table 5

\begin{tabular}{|c|c|c|c|c|c|c|c|c|c|c|c|c|c|c|c|c|c|}
\hline & & & \multicolumn{15}{|c|}{ Band number } \\
\hline$\frac{\text { D.noxia }}{\text { population }}$ & & & 4 & 5 & 6 & 7 & 8 & 9 & & $\begin{array}{l}1 \\
1\end{array}$ & $\begin{array}{l}1 \\
2\end{array}$ & $\begin{array}{l}1 \\
3\end{array}$ & $\begin{array}{l}1 \\
4\end{array}$ & $\begin{array}{l}1 \\
5\end{array}$ & & & $\begin{array}{l}1 \\
8\end{array}$ \\
\hline Californie, & USA & 1 & 1 & 1 & 0 & 1 & 0 & 0 & 0 & 1 & 1 & 1 & 1 & 0 & 1 & 0 & 0 \\
\hline Californie, U & USA & 2 & 1 & 1 & 0 & 1 & 0 & 0 & 0 & 1 & 1 & 1 & 1 & 0 & 1 & 0 & 0 \\
\hline California, L & USA & 3 & 1 & 1 & 0 & 1 & 0 & 0 & 0 & 1 & 1 & 1 & 1 & 0 & 1 & 0 & 0 \\
\hline California, & USA & 4 & 1 & 1 & 0 & 1 & 0 & 0 & 0 & 1 & 1 & 1 & 1 & 0 & 1 & 0 & 0 \\
\hline California, L & USA & 5 & 1 & 1 & 0 & 1 & 0 & 0 & 0 & 1 & 1 & 1 & 1 & 0 & 1 & 0 & 0 \\
\hline California, L & USA & 6 & 1 & 1 & 0 & 1 & 0 & 0 & 0 & 1 & 1 & 1 & 1 & 0 & 1 & 0 & 0 \\
\hline Californie, U & USA & 7 & 1 & 1 & 0 & 1 & 0 & 0 & 0 & 1 & 1 & 1 & 1 & 0 & 1 & 0 & 0 \\
\hline California, & USA & 8 & 1 & 1 & 0 & 1 & 0 & 0 & 0 & 1 & 1 & 1 & 1 & 01 & 1 & 0 & 0 \\
\hline California, & USA & 9 & 1 & 1 & 0 & 1 & 0 & 0 & 0 & 1 & 1 & 1 & 1 & 0 & 1 & 0 & 0 \\
\hline California, & USA & 10 & 1 & 1 & 0 & 1 & 0 & 0 & 0 & 1 & 1 & 1 & 1 & 0 & 1 & 0 & 0 \\
\hline Canada & 1 & & 1 & 1 & 0 & 1 & 0 & 0 & 0 & 1 & 1 & 1 & 1 & 11 & 1 & 0 & 1 \\
\hline Canada & 2 & & 1 & $i$ & 0 & 1 & 0 & 0 & 0 & 1 & 1 & 1 & 1 & 11 & 1 & 0 & 1 \\
\hline Canada & 3 & & 1 & 1 & 0 & 1 & 0 & 0 & 0 & 1 & 1 & 1 & 1 & 11 & 1 & 0 & 1 \\
\hline Canada & 4 & & 1 & 1 & 0 & 1 & 0 & 0 & 0 & 1 & 9 & 1 & 1 & 11 & 1 & 0 & 1 \\
\hline Canada & 5 & & 1 & 1 & 0 & 1 & 0 & 0 & 0 & 1 & 1 & 1 & 1 & 11 & 1 & 0 & 1 \\
\hline Canada & 6 & & 1 & 1 & 0 & 1 & 0 & 0 & 0 & 1 & 1 & 1 & 1 & 11 & 1 & 0 & 1 \\
\hline Canada & 7 & & 1 & 1 & 0 & 1 & 0 & 0 & 0 & 1 & 1 & 1 & 1 & 11 & 1 & 0 & 1 \\
\hline Canada & 8 & & 1 & 1 & 0 & 1 & 0 & 0 & 0 & 1 & 1 & 1 & 1 & 11 & 1 & 0 & 1 \\
\hline Canada & 9 & & 1 & 1 & 0 & 1 & 0 & 0 & 0 & 1 & 1 & 1 & 1 & 11 & 1 & 0 & $\uparrow$ \\
\hline Canada & 10 & & 1 & 1 & 0 & 1 & 0 & 0 & 0 & 1 & 1 & 1 & 1 & 11 & 1 & 0 & 1 \\
\hline South Afric & ca 1 & & 1 & 1 & 0 & 1 & 0 & 0 & 0 & 1 & 1 & 1 & 1 & 01 & 1 & 0 & 1 \\
\hline South Afric & ca 2 & & 0 & 1 & 0 & 1 & 0 & 0 & 0 & 1 & 1 & 1 & 1 & 1 & 1 & 0 & 1 \\
\hline South Afric & ca 3 & & 1 & 1 & 0 & 1 & 0 & 0 & 0 & 1 & 1 & 1 & 1 & 0 & 1 & 0 & 1 \\
\hline South Afric & ca 4 & & 1 & 1 & 0 & 1 & 0 & 0 & 0 & 1 & 1 & 1 & 1 & 0 & 1 & 0 & $\uparrow$ \\
\hline South Afric & ca 5 & & 0 & 1 & 0 & 1 & 0 & 0 & 0 & 1 & 1 & 1 & 1 & 11 & 1 & 0 & 1 \\
\hline South Afric & ca 6 & & 1 & 1 & 0 & 1 & 0 & 0 & 0 & 1 & 1 & 1 & 1 & 0 & 1 & 0 & 1 \\
\hline South Afric & ca 7 & & 1 & 1 & 0 & 1 & 0 & 0 & 0 & 1 & 1 & 1 & 1 & 0 & 1 & 0 & 1 \\
\hline South Afric & ca 8 & & 1 & 1 & 0 & 1 & 0 & 0 & 0 & 1 & 1 & 1 & 1 & 01 & 1 & 0 & 1 \\
\hline South Afric & ca 9 & & 1 & 1 & 0 & 1 & 0 & 0 & 0 & 1 & 1 & 1 & 1 & 01 & 1 & 0 & 1 \\
\hline South Afric & ca 10 & & 1 & 1 & 0 & 1 & 0 & 0 & 0 & 1 & 1 & 1 & 1 & 01 & 1 & 0 & 1 \\
\hline Seranon, FF & $=R \quad 1$ & & 1 & 1 & 0 & 1 & 0 & 1 & 0 & 1 & 1 & 1 & 1 & 01 & 1 & 0 & 0 \\
\hline Seranon, FF & $=R \quad 2$ & & 1 & 1 & 0 & 1 & 0 & 1 & 0 & 1 & 1 & 1 & 1 & 0 & i & 0 & 0 \\
\hline Seranon, FF & $=R \quad 3$ & & 1 & 1 & 0 & 1 & 0 & 1 & 0 & 1 & 1 & 1 & 1 & 01 & 1 & 0 & 0 \\
\hline Seranon, FF & $=R \quad 4$ & & 1 & 1 & 0 & 1 & 0 & 1 & 0 & 1 & 1 & 1 & 1 & 01 & 1 & 0 & 0 \\
\hline Seranon, FF & $=R \quad 5$ & & 1 & 1 & 0 & 1 & 0 & 1 & 0 & 1 & 1 & 1 & 1 & 01 & 1 & 0 & 0 \\
\hline Seranon, FF & R 6 & & 1 & 1 & 0 & 1 & 0 & 1 & 0 & 1 & 1 & 1 & 1 & 01 & 1 & 0 & 0 \\
\hline Seranon, FF & : 7 & & 1 & 1 & 0 & 1 & 0 & 1 & 0 & 1 & 1 & 1 & 1 & 01 & 1 & 0 & 0 \\
\hline Seranon, FF & $=R \quad 8$ & & 1 & 1 & 0 & 1 & 0 & 1 & 0 & 1 & 1 & 1 & 1 & 01 & 1 & 0 & 0 \\
\hline Seranon, FF & R 9 & & 1 & 1 & 0 & 1 & 0 & 1 & 0 & 1 & 1 & 1 & 1 & 01 & 1 & 0 & 0 \\
\hline Seranon, FF & $=R \quad 10$ & & 1 & 1 & 0 & 1 & 0 & 1 & 0 & 1 & 1 & 1 & 1 & 01 & 1 & 0 & 0 \\
\hline Antibes, FR & $R \quad 1$ & & 1 & 1 & 0 & 1 & 0 & 1 & 0 & 1 & 1 & 1 & 1 & 01 & 1 & 0 & 0 \\
\hline Antibes, FR & R 2 & & 1 & 1 & 0 & 1 & 0 & 1 & 0 & 1 & 1 & 1 & 1 & 01 & 1 & 0 & 0 \\
\hline Antibes, $F R$ & R 3 & & 1 & 1 & 0 & 1 & 0 & 1 & 0 & 1 & 1 & 1 & 1 & 09 & 1 & 0 & 0 \\
\hline Antibes, FA & ค 4 & & 1 & 1 & 0 & 1 & 0 & 1 & 0 & 1 & 1 & 1 & 1 & 01 & 1 & 0 & 0 \\
\hline Antibes, FR & R 5 & & 1 & 1 & 0 & 1 & 0 & 1 & 0 & 1 & 1 & 1 & 1 & 01 & 1 & 0 & 0 \\
\hline Antibes, FR & R 6 & & 1 & 1 & 0 & 1 & 0 & 1 & 0 & 1 & 1 & 1 & 1 & 01 & 1 & 0 & 0 \\
\hline Antibes, FR & R 7 & & 1 & 1 & 0 & 1 & 0 & 1 & 0 & 1 & 1 & 1 & 1 & 01 & 1 & 0 & 0 \\
\hline Antibes, FR & R 8 & & 1 & 1 & 0 & 1 & 0 & 1 & 0 & 1 & 1 & 1 & 1 & 01 & 1 & 0 & 0 \\
\hline Antibes, FR & $R \quad 9$ & & 1 & 1 & 0 & 1 & 0 & 1 & 0 & 1 & 1 & 1 & 1 & 01 & 1 & 0 & 0 \\
\hline Antibes, FR & R 10 & & 1 & 1 & 0 & 1 & 0 & 1 & 0 & 1 & 1 & 1 & 1 & 01 & 1 & 0 & 0 \\
\hline Jordan & 1 & & 1 & 0 & 1 & 1 & 0 & 0 & 0 & 1 & 1 & 0 & 1 & 0 & 1 & 1 & 0 \\
\hline Jordan & 2 & & 1 & 0 & 1 & 1 & 0 & 0 & 0 & 1 & 1 & 0 & 1 & 0 & 1 & 1 & 0 \\
\hline Jordan & 3 & & 1 & 0 & 1 & 1 & 0 & 0 & 0 & 1 & 1 & 0 & 1 & 01 & 1 & 1 & 0 \\
\hline Jordan & 4 & & 1 & 0 & 1 & 1 & 0 & 0 & 0 & 1 & 1 & 0 & 1 & 01 & 1 & 1 & 0 \\
\hline Jordan & 5 & & 1 & 0 & 1 & 1 & 0 & 0 & 0 & 1 & 1 & 0 & 1 & 01 & 1 & 1 & 0 \\
\hline Jordan & 6 & & 1 & 0 & 1 & 1 & 0 & 0 & 0 & 1 & 1 & 0 & 1 & 0 & 1 & 1 & 0 \\
\hline Jordan & 7 & & 1 & 0 & 1 & 1 & 0 & 0 & 0 & 1 & 1 & 0 & 1 & 0 & 1 & 1 & 0 \\
\hline Jordan & 8 & & 1 & 0 & 1 & 1 & 0 & 0 & 0 & 1 & 1 & 0 & 1 & 01 & 1 & 1 & 0 \\
\hline Jordan & 9 & & 1 & 0 & 1 & 1 & 0 & 0 & 0 & 1 & 1 & 0 & 1 & 01 & 1 & 1 & 0 \\
\hline Jordan & 10 & & 1 & 0 & 1 & 1 & 0 & 0 & 0 & 1 & 1 & 0 & 1 & 0 & 1 & 1 & 0 \\
\hline
\end{tabular}

Table 7 Continued

\begin{tabular}{|c|c|c|c|c|c|c|c|c|c|c|c|c|c|c|c|c|}
\hline \multirow[b]{2}{*}{ D.noxis } & & \multicolumn{15}{|c|}{ Band number } \\
\hline & $\overline{\text { population }}$ & 4 & 5 & 6 & 7 & 8 & 9 & $\begin{array}{l}1 \\
0\end{array}$ & $\begin{array}{l}1 \\
1\end{array}$ & $\begin{array}{l}1 \\
2\end{array}$ & $\begin{array}{l}1 \\
3\end{array}$ & & $\begin{array}{l}1 \\
5\end{array}$ & & & $\begin{array}{l}1 \\
8\end{array}$ \\
\hline Syrio & 1 & 1 & 0 & 1 & 1 & 0 & 0 & 1 & 1 & 1 & 0 & 1 & 0 & 1 & 0 & 1 \\
\hline Syria & 2 & 1 & 0 & 1 & 1 & 0 & 0 & 1 & 1 & 1 & 0 & 1 & 0 & 1 & 0 & 1 \\
\hline Syria & 3 & 1 & 0 & 1 & 1 & 0 & 0 & 1 & 1 & 1 & 0 & 1 & 0 & 1 & 0 & 1 \\
\hline Syria & 4 & 1 & 0 & 1 & 1 & 0 & 0 & 1 & 1 & 1 & 0 & 1 & 0 & 1 & 0 & 1 \\
\hline Syria & 5 & 1 & 0 & 1 & 1 & 0 & 0 & 1 & 1 & 1 & 0 & 1 & 0 & 1 & 0 & 1 \\
\hline Syria & 6 & 1 & 0 & 1 & 1 & 0 & 0 & 1 & 1 & 1 & 0 & 1 & 0 & 1 & 0 & 1 \\
\hline Syria & 7 & 1 & 0 & 1 & 1 & 0 & 0 & 1 & 1 & 1 & 0 & 1 & 0 & 1 & 0 & 1 \\
\hline Syrie & 8 & 1 & 0 & 1 & 1 & 0 & 0 & 1 & 1 & 1 & 0 & 1 & 0 & 1 & 0 & 1 \\
\hline Syria & 9 & 1 & 0 & 1 & 1 & 0 & 0 & 1 & 1 & 1 & 0 & 1 & 0 & 1 & 0 & 1 \\
\hline Syria & 10 & 1 & 0 & 1 & 1 & 0 & 0 & 1 & 1 & 1 & 0 & 1 & 0 & 1 & 0 & 1 \\
\hline
\end{tabular}

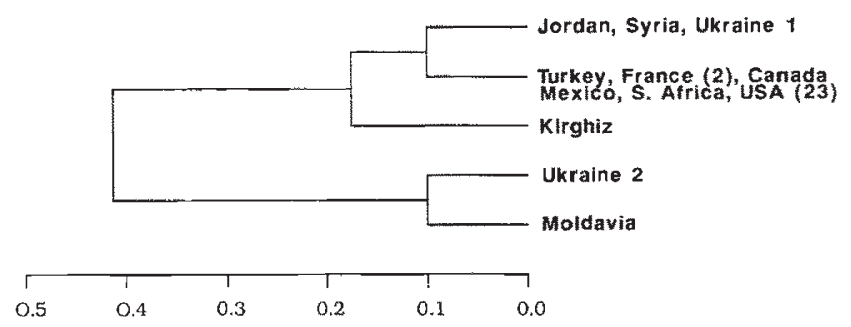

Nei's Unbiased Genetic Distance

Fig. 3 Dendrogram showing the phenetic relationships among $D$. noxia from various locations throughout the world, based on three polymorphic enzyme loci. Number of locations represented within a country $(n)$; Ukraine $1=$ Crimean Peninsula, Ukraine; Ukraine $2=$ Kerson, Ukraine.

populations. These results demonstrate what has long been suspected: allozyme analysis does not adequately reflect the true level of genetic variation in aphids. The same observation has been made using DNA fingerprinting techniques (Carvalho et al., 1991; Shufran et al., 1991).

Most of the allozyme and RAPD-PCR diversity was found among populations in the eastern and northeastern Mediterranean regions. The factors responsible for this diversity could be the holocyclic life cycle documented in these regions. D. noxia populations in the Ukraine are holocyclic (Kiriac et al., 1990) and this may account for the two distinct allelomorphs. Using either RAPD-PCR or allozyme markers, very little genetic variation was found within a population. This was true of collections from areas in which the aphid was introduced recently as well as those made throughout its native habitat. We have no explanation for the absence of diversity found within populations using RAPD-PCR markers despite finding substantial variation among collections. Lack of regional genetic varia- 
Fig. 4 (A) Dendrogram showing the phenetic relationships among $D$. noxia from various locations throughout the world, based on genetic polymorphisms generated by RAPD-PCR. This dendrogram was constructed using all 69 polymorphic bands. (B) Dendrogram showing the phenetic relationships among $D$. noxia from various locations throughout the world, based on genetic polymorphisms generated by RAPD-PCR. This dendrogram was constructed using only the 28 wellamplified polymorphic bands.

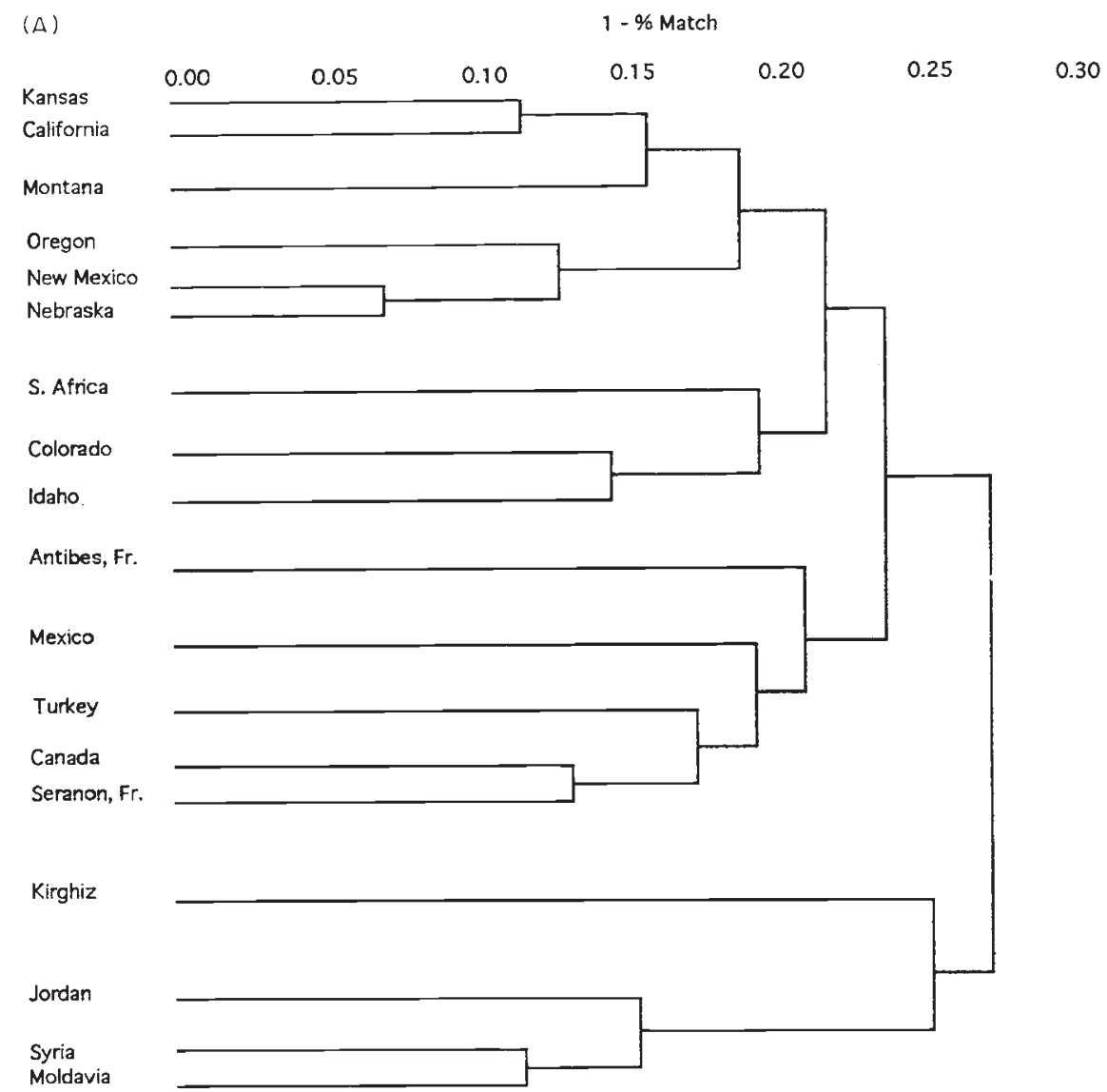

(B)
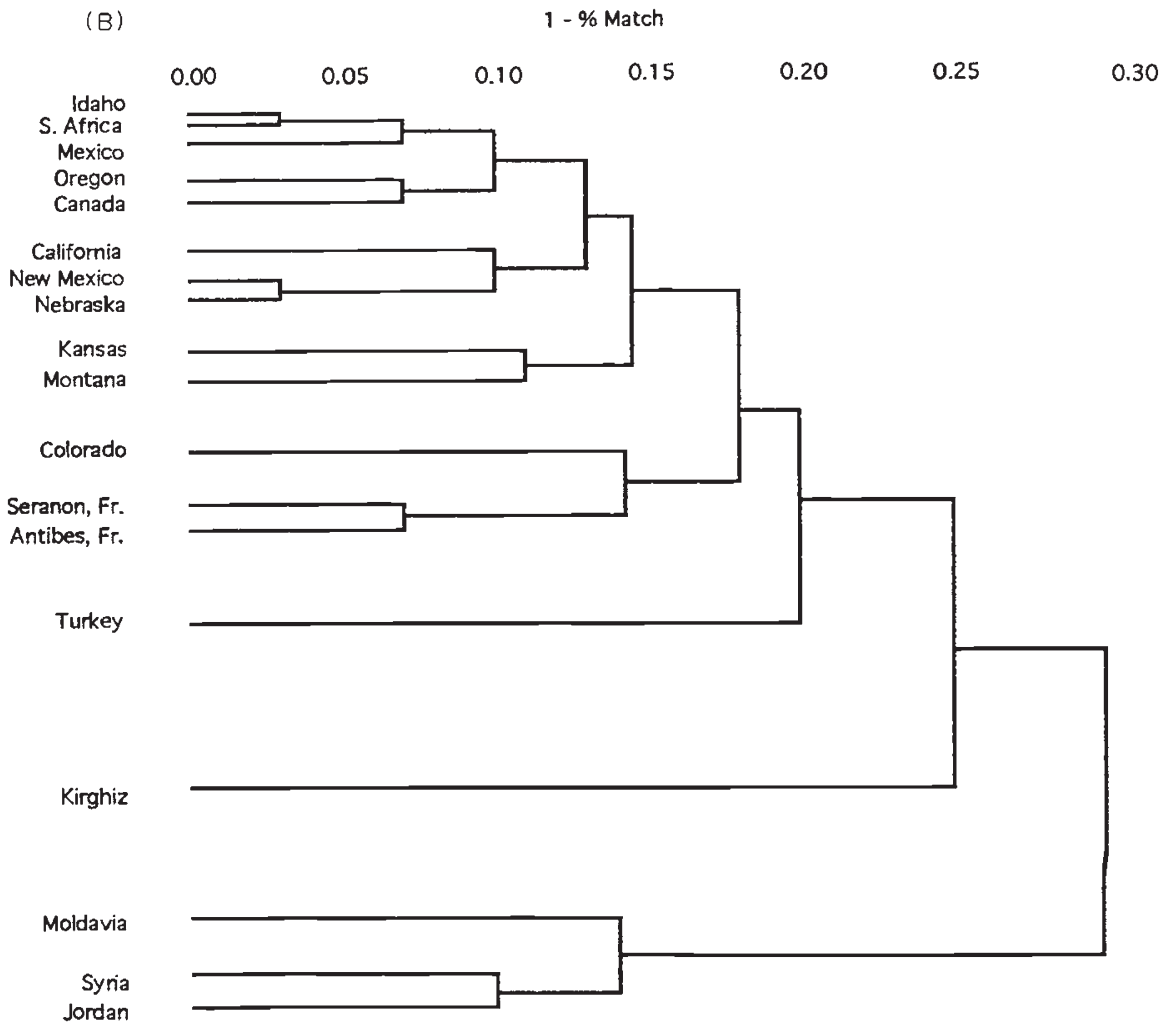
tion in other aphid species has been attributed to directional selection acting on parthenogenetic clones (Blackman, 1985; Wool et al., 1978; Soumalainen et al., 1980; Simon et al., 1982) and founder effects (May \& Holbrook, 1978; Steiner et al., 1985b). The few surviving genotypes rapidly dominated niches within a region through their well-developed migration mechanism (flight) and parthenogenetic reproduction.

Studies on the biotypic status of these same $D$. noxia clones from Turkey, Syria, France, Moldavia, Kirghiz and U.S.A. indicated that these are all unique biotypes that must differ genetically (Puterka et al., 1992). The Seranon, France, clone was biotypically most similar to the U.S.A. clone, but even these two clones differed in virulence to at least two cereal accessions. Such comparisons indicate that allozyme variation is randomly associated with the biotype trait. In rare cases, allozyme variation has been shown to correspond with host specificity as in Macrosiphum euphorbiae (Thomas) (Steiner et al., 1985a) and Aphis fabae (Scopoli) (Furk, 1979). However, there have been many cases where allozyme variation was not detected in aphid host races or biotypes (May \& Holbrook, 1978; Beregovoy \& Starks, 1986) or had no bearing on hostspecificity (Abid et al., 1989; Simon et al., 1982; Steiner et al., 1985a). The presence of distinct biotypes within the same allelomorphs suggests that biotypes are a recent development in the evolutionary history of $D$. noxia.

There was perfect agreement in the phylogenies derived by allozyme and RAPD-PCR analysis, with the exception of the placement of populations from Kirghiz and Moldavia with respect to those from Syria and Jordan. Both suggest that the French, South African, Mexican and U.S.A. populations shared a common origin and that they may have originated in Turkey. This pattern was also suggested by the biotype data (Puterka et al., 1992). The lack of correspondence between geographical distance and genetic distance in the U.S.A. may suggest random establishment of clones through commerce rather than through migration. A similar pattern was observed in the mosquito Aedes albopictus, following its introduction into the U.S.A. (Black et al., 1988). The species is known to be transported over long regions by tyre commerce (Hawley et al., 1987). More extensive sampling of several locations within each state will be needed to test this hypothesis in $D$. noxia populations.

\section{Acknowledgements}

We thank the following colleagues for collecting and sending the aphid samples used in this study: P. Burnett, CIMMYT, Mexico; R. Butts, Research
Station, Lethbridge, Canada; R. Campbell, Oklahoma State University, Stillwater; G. Hein, University of Nebraska Panhandle Research and Ext. Ctr., Scottsbluff; K. Hopper, USDA, ARS, EBL, Montpellier, France; D. Jackson, Oregon State Experimental Station, Hermiston; G. Johnson and K. Kammerzell, Montana State University, Bozeman; D. Kindler, USDA, ARS, PSRL, Stillwater, Oklahoma; R. Miller, ICARDA, Aleppo, Syria; E. Natwick, Coop. Ext. Ser., El Centro, California; B. Neish, New Mexico State University Ext. Ser., Morierity; T. Poprawski, USDA, ARS, Ithaca, N.Y.; J. Slosser and L. Bush, Texas A\&M University Research and Ext. Ctr., Vernon; C. Sorenson, Nevada Ext. Ser., Reno; M. Stoltz, Oregon State Experimental Station, Pendleton.

\section{References}

ABID, H. S., KINDLER, S. D., JENSEN, S. G., THOMAS-COMPTON, M. A. AND SPOMER, s. M. 1989. Isozyme characterization of sorghum aphid species and greenbug biotypes. Ann. Entomol. Soc. Am., 82, 303-306.

BERANEK, I. P. 1974. Esterase variation and organophosphate resistance in populations of Aphis fabae and Myzus persicae. Entomol. Exp. Appl., 17, 381-390.

BEREGOVOY, V. H. AND STARKS, K. J. 1986. Enzyme patterns in biotypes of greenbug, Schizaphis graminum (Rondani) (Homoptera: Aphididae). J. Kan. Entomol. Soc., 59, $517-523$.

BERGMAN, D. K., DILLWITH, J. W., CAMPBELL, R. K. AND EIKENBARY, R. D. 1990. Cuticular hydrocarbons of the Russian wheat aphid. S. W. Entomol., 15, 91-100.

BLACK, W. C., IV AND KRAFSUR, E. S. 1985. Electrophoretic analysis of genetic variability in the house fly (Musca domestica L.). Biochem. Genet., 23, 191-201.

BLACK, W. C., IV, FERRARI, J. A., RAI, K. S. AND SPRENGER, D. A. 1988. Breeding structure of a colonizing species: Aedes albopictus in the United States. Heredity, 60, 173-181.

BLACK, W. C., IV, DUTEAU, N. M., PUTERKA, G. J., NECHOLS, J. R. AND PETTORINI, J. M. 1992. Use of the random amplified polymorphic DNA polymerase chain reaction (RAPD-PCR) to detect DNA polymorphisms in aphids. Bull. Entomol. Res., 82, 151-159.

BLACKMAN, R. L. 1985. Aphid cytology and genetics. In: Szelegiewicz, H. (ed.) Evolution and Biosystematics of Aphids. Proceedings of the International Aphid Symposium, Jabolona, Poland, pp. 171-237.

BRIGGS, J. B. 1965. The distribution, abundance, and genetic relationships of four strains of the rubus aphid (Amphorophora rubi Kalt.) in relation to raspberry breeding. J. Hort. Sci., 40, 109-117.

BUSH, L., SLOSSER, J. E. AND WORRALL, W. D. 1989. Variations in damage to wheat caused by the Russian wheat aphid (Homoptera: Aphididae) in Texas. J. Econ. Entomol., 82, 466-472.

CARVAlHO, G. R., MACleAN, N., WRATTEN, S. D., CARTER, R. E. AND THURSTON, J. P. 1991. Differentiation of aphid clones using 
DNA fingerprints from individual aphids. Proc. $R$. Soc. London. B, 243, 109-114.

FURK, C. 1979. Field collections of Aphis fabae Scopoli s. lat. (Homoptera: Aphididae) studied by starch gel electrophoresis and isoelectric focusing. Comp. Biochem. Physiol., 62b, 225-230.

GILCHRIST, L. 1., RODRIGUEZ, R. AND BURNETT, P. A. 1984. The extent of freestate streak and Diuraphis noxia in Mexico. In: Burnett, P. and Havener, R. R. (eds) Barley Yellow Dwarf, a Proceedings of the Workshop. International Maize and Wheat Improvement Center (СіммYт), Mexico City, pp. 157-163.

GROSSHEIM, N. A. 1914. The barley aphid, Brachycolus noxius Mordvilko. In: Memoirs of the National History Museum of the Zemstvo of the Government of Taurida, Simferopol III, pp. 35-78.

HAWLEY, W. A., REITER, P., COPELAND, R. S., PUMPUNI, C. B. AND CRAIG, G. B., JR. 1987. Aedes albopictus in North America: probable introduction in used tires from northern Asia. Science, 236, 1114-1116.

KAMBHAMPAT1, S., BLACK, W. C., IV AND RA1, K. S. 1991. Geographic origin of U.S. and Brazilian Aedes albopictus inferred from allozyme analysis. Heredity, 67, 85-94.

KAMBHAMPAT1, S., BLACK, W. C., IV AND RAI, K. S. 1992. RAPDPCR for identification and differentiation of mosquito species and populations: techniques and statistical analysis. J. Med. Entomol.,29, 939-945.

KINDLER, S. D. AND SPRINGER, T. L. 1989. Alternate hosts of the Russian wheat aphid (Homoptera: Aphididae). J. Econ. Entomol., 82, 1358-1362.

KIRIAC, 1., GRUBER, F., POPRAWSK1, T., HALBERT, S. AND ELBERSON, L. 1990. Occurrence of sexual morphs of Russian wheat aphid, Diuraphis noxia (Homoptera: Aphididae), in several locations in the Soviet Union and the northwestern United States. Proc. Entomol. Soc. Wash., 92, 544-547.

LOXDALE, H. D., CASTANERA, P. AND BROOKES, C. P. 1983. Electrophoretic study of enzymes from cereal aphid populations. I. Electrophoretic techniques and staining systems for characterizing isoenzymes from six species of cereal aphids. Bull. Entomol. Res., 73, 645-657.

LOXDALE, H. D., RHODES, J. A. AND FOX, J. S. 1985. Electrophoretic study of enzymes from cereal aphid populations. 4. Detection of hidden genetic variation within populations of the grain aphid, Sitobion avenae (F.) (Hemiptera: Aphididae). Theor. Appl. Gen., 70, 407-412.

MCCAMMON, R. B. AND WENNINGER, G. 1970. The dendrograph. Kansas Geological Survey Computer Contribution No. 48, pp. 28.

MACK, T. P. AND SMILOWITZ, Z. 1980. Soluble protein electrophoretic patterns from two biotypes of Myzus persicae. Am. Potato J., 57, 365-369.

MAY, B. AND HOLBROOK, F. R. 1978. Absence of genetic variability in the green peach aphid, Myzus persicae (Hemiptera: Aphididae). Ann. Entomol. Soc. Am., 71, 809-812.

NEI, M. 1978. Estimation of average heterozygosity and genetic distance from a small number of individuals. Genetics, 89, 583-590.

PASTEUR, N., PASTEUR G., BONHOMME, F., CATALAN, J. AND BRITTONDAVIDIAN, J. 1988. Practical Isozyme Genetics. Ellis
Horwood Ltd., Chichester, pp. 215.

POWELL, J. R., TABACHNICK, w. J. AND ARNOLD, J. 1980. Genetics and the origin of a vector population: Aedes aegypti, a case study. Science, 208, 1385-1387.

POWERS, T. O., JENSEN, S. G., KINDLER, S. D., STRYKER, C. J. AND SANDALL, L. J. 1989. Mitochondrial DNA divergence among greenbug (Homoptera: Aphididae) biotypes. Ann. Entomol. Soc. Am., 82, 298-302.

PUTERKA, G. J. AND PETERS, D. C. 1989. Inheritance of greenbug virulence to $G b 2$ and $G b 3$ resistance genes in wheat. Genome, 32, 109-114.

PUTERKA, G. J. AND PETERS, D. C. 1990. Sexual reproduction and inheritance of virulence in the greenbug, Schizaphis graminum (Rondani). In: Campbell, R. K. and Eikenbary, R. D. (eds) Aphid-Plant Genotype Interactions. Elsevier Science Publishers, Amsterdam, pp. 289-318.

PUTERKA, G. J. AND BURTON, R. L. 1991. Aphid genetics in relation to host plant resistance. In: Peters, D. C., Webster, J. and Chlouber, C. S. (eds) Proceedings, Aphid-Plant Interactions: Populations to Molecules, 12-17 August, 1990, MP-132. Oklahoma Agricultural Experimental Station, Stillwater, pp. 59-69.

PUTERKA, G. J., BURD, J. D. AND BURTON, R. L. 1992. Biotypic variation in a worldwide collection of Russian wheat aphid (Homoptera: Aphididae). J. Econ. Entomol., 85, 1497-1506.

RHOMBERG, L. R., JOSEPH, S. AND SINGH, R. S. 1985. Seasonal and clonal selection in cyclically parthenogenetic rose aphids (Macrosiphum rosae). Can. J. Genet. Cytol., 27, 224-232.

SHUFRAN, K. A., BLACK, W. C., IV AND MARGOLIES, D. C. 1991. DNA fingerprinting to study spatial and temporal distributions of an aphid, Schizaphis graminum (Homoptera: Aphididae). Bull. Entomol. Res., 81, 303-313.

SIMON, C., PARENT, M. A. AND AUCLAIR, J. L. 1982. Isozyme analysis of biotypes and field populations of the pea aphid, Acyrithosiphon pisum. Entomol. Exp. Appl., 32, 186-192.

SINGH, S. M. AND CUNNINGHAM, T. K. 1981. Morphological and genetic differentiation in aphids (Aphididae). Can. Entomol., 113, 539-550.

STEINER, w. W. M. 1988. Electrophoretic techniques for the genetic study of aphids. In: Minks, A. K. and Harrewijn, P. (eds) Aphids, Their Biology, Natural Enemies and Control, vol. B., Elsevier Science Publishers, Amsterdam, pp. $135-143$.

STEINER, W. W. M. AND JOSLYN, D. J. 1979. Electrophoretic techniques for the study of mosquitoes. Mosquito News, 39, $35-54$.

STEINER, W. W. M., VOEGTLIN, D. J., IRWIN, M. E. AND KAMPMEIER, G. 1985a. Electrophoretic comparison of aphid species: Detecting differences based on taxonomic status and host plant. Comp. Biochem. Physiol., 81, 295-299.

STEINER, W. W. M., VOEGTLIN, D. J. AND IRWIN, M. E. 1985b. Genetic differentiation and its bearing on migration in North American populations of the corn leaf aphid, Rhopalosiphum maidis (Fitch) (Homoptera: Aphididae). Ann. Entomol. Soc. Am., 78, 518-525.

STOETZEL, M. B. 1987. Information on and identification of $D i$ uraphis noxia (Homoptera: Aphididae) and other aphid 
species colonizing leaves of wheat and barley in the United States. J. Econ. Entomol., 80, 696-704.

SUOMALAINEN, E., SAURA, A., LOKKI, J. AND TEERI, T. 1980. Genetic polymorphism and evolution in parthenogenetic animals. IX. Absence of variation within parthenogenetic aphid clones. Theor. Appl. Genet., 57, 129-132.

SWOFFORD, D. L. AND SELANDER, R. B. 1981. BIOSYS-1: a FORTRAN program for the comprehensive analysis of electrophoretic data in population genetics and systematics. $J$. Heredity, 72, 281-283.

TOMIUK, J. AND WORHMANN, $\mathrm{K}, 1980$. Enzyme variability in populations of aphids. Theor. Appl. Genet., 57, 129-132. TOMIUK, J. AND WORHMANN, K. 1981. Changes of genotype frequencies at the $M D H$ locus in populations of Macrosiphum rosae (L) (Hemiptera: Aphididae). Z. ang. Entomol., 90, 464-473.
TOMIUK, J. AND WORHMANN, K. 1983. Enzyme polymorphism and taxonomy of aphid species. Z. Zool. Syst. Evolutionsforsch., 21, 266-274.

TOMIUK, J., WORHMANN, K. AND EGGERS-SCHUMACHER, H. A. 1979. Enzyme patterns characteristic for the identification of aphid species, Z. ang. Entomol., 88, 440-446.

WALTERS, M. C., DU TOIT, F., BOTHA, T. C., AALBERSBERG, K., HEWITT, P. H. AND BROODRYK, S. w. 1980. The Russian wheat aphid. Farming South African Leaflet Series Wheat G.3.

WILLIAMS, J. G. K., KUBELIK, A. R., LIVAK, K. J., RAFALSKI, J. A. AND TINGEY, S. V. 1990. DNA polymorphisms amplified by arbitrary primers are useful as genetic markers. Nuc. Acids Res., 18, 6531-6535.

WOOL, D., VAN EMDEN, H. F., BUNTING, S. W. 1978. Electrophoretic study of genetic variation in British Myzus persicae (Hemiptera: Aphididae). Biochem. Genet., 16, 987-1006. 